\title{
Model Penyelesaian Sengketa dan Peradilan Adat di Aceh
}

\author{
Nanda Amalia, Mukhlis, dan Yusrizal \\ Fakultas Hukum Universitas Malikussaleh Aceh - Indonesia \\ Komplek Kampus Bukit Indah, Jln. Jawa No. 1, Muara Satu - Lhokseumawe, Aceh \\ nanda.amalia@unimal.ac.id; mukhlis.dr@unimal.ac.id; yusrizal.dr@unimal.ac.id
}

Received: 14 Oktober 2017; Accepted: 4 Juni 2018; Published: 14 Agustus 2018

DOI: 10.20885/iustum.vol25.iss1.art8

\begin{abstract}
This research had two objectives: first to explore the opinions of Aceh community, especially those who lived in Gampong (village) area, about the implementation of customary court in Gampong and second to illustrate the dispute resolution models used by the Gampong Customary Court and any considerations underlying its judgment in making decisions. This was a qualitative research, using a socio-legal approach that specifically took place in Lhokseumawe, Northern Aceh, Meulaboh and Tapak Tuan. In addition to literature studies, the data collection was also done through field research. This study concluded that, first, the existence of Gampong customary court is perceived by the society to have an alternative and positive potential as the resolution of minor violations that could be resolved by the community. In addition, the existence of this customary court could reduce the accumulated cases in court as well as could help the community access the protection of their rights. Second, there are two models of dispute resolution in Gampong, namely a simple dispute resolution model with the involvement of Geuchik and the element of Tuha Peut Gampong. Another model is a dispute resolution model that resembles formal trials based on the customary court guidelines issued by Aceh Customary Board.
\end{abstract}

Keywords: Custom; customary court system; dispute resolution

\section{Abstrak}

Terdapat dua tujuan dalam penelitian ini, pertama, untuk mengeksplorasi pandangan masyarakat Aceh terutama masyarakat pada daerah Gampong (perkampungan) tentang penerapan peradilan adat di Gampong. Kedua, studi ini juga akan menggambarkan model-model penyelesaian sengketa yang digunakan oleh Majelis Peradilan Adat Gampong dan hal-hal yang mendasari pertimbangannya dalam menetapkan keputusan. Penelitian ini merupakan penelitian kualitatif, dengan menggunakan pendekatan sosio-legal yang secara khusus mengambil lokasi penelitian di Lhokseumawe, Aceh Utara, Meulaboh dan Tapak Tuan. Selain studi kepustakaan, kegiatan pengumpulan data juga didapatkan melalui penelitian lapangan. Studi ini menyimpulkan pertama, keberadaan peradilan adat Gampong dipandang masyarakat sebagai alternatif dan potensi positif dalam penyelesaian pelanggaran ringan yang bisa diatasi oleh masyarakat. Selain itu, adanya peradilan adat ini dapat mengurangi akumulasi kasus di pengadilan dan dapat membantu warga mengakses perlindungan hak mereka. Kedua, terdapat dua model penyelesaian sengketa di Gampong, yakni model penyelesaian sengketa yang sederhana dengan keterlibatan Geuchik dan pelibatan unsur Tuha Peut Gampong secara keseluruhan. Model lainnya yakni model penyelesaian sengketa yang menyerupai persidangan formil dan merujuk kepada pedoman peradilan adat yang diterbitkan oleh Majelis Adat Aceh.

Kata-kata Kunci: Adat; sistem peradilan adat; penyelesaian sengketa 


\section{Pendahuluan}

Berbagai studi yang membahas tentang peradilan adat dalam berbagai konteks telah menunjukkan arti penting praktek-praktek penyelesaian sengketa yang dilakukan oleh masyarakat dengan cara berdamai. Beberapa tulisan yang dapat dilacak, misalnya Abdurrahman ${ }^{1}$, Hedar Laudjeng', Yance Arizona ${ }^{3}$, Kelompok Kerja Akses terhadap Keadilan", Rikardo Simarmata ${ }^{5}$, Ahmadi Hasan ${ }^{6}$, Edy Sanjaya7, Herlambang Perdana Wiratraman" ${ }^{8}$, Tody Sasmita Jiwa Utama \& Sandra Dini Febry Aristya ${ }^{9}$ dan Lilik Mulyadi ${ }^{10}$ telah mengungkapkan realitas posisi penting peradilan adat yang hadir di dalam masyarakat adat dan keberadaannya dipertimbangkan sebagai alternatif pemberi keadilan di samping lembaga peradilan formal. Keberadaan peradilan adat juga dianggap relevan dengan sistem peradilan di Indonesia baik dalam ranah perdata maupun pidana. Keberadaan peradilan formal bagi masyarakat perkampungan dianggap masih sulit untuk dijangkau, tidak hanya dikarenakan akses menuju peradilan yang jauh dari masyarakat kampung, namun juga dikarenakan biaya tinggi yang harus dikeluarkan serta rumitnya administrasi peradilan yang harus dipenuhi oleh masyarakat. Peradilan adat sebagai bagian dari hak tradisional kesatuan

${ }^{1}$ Abdurrahman, "Penyelesaian Sengketa Melalui Pendekatan Adat", Qanun Jurnal Ilmu Hukum No. 50 Edisi April 2010, FH Unsyiah, Banda Aceh, 2010.

2 Hedar Laudjeng, Mempertimbangkan Peradilan Adat, Seri Pengembangan Wacana No. 4 - Penerbit Perkumpulan untuk Pembaharuan Hukum Berbasis Masyarakat dan Ekologis (HuMa), The Ford Foundation \& Interchurch Organization for Development Co-operation (ICCO), 2003.

${ }^{3}$ Yance Arizona, "Kedudukan Peradilan Adat dalam Sistem Hukum Nasional", Makalah disampaikan pada Diskusi tentang Memperkuat Peradilan Adat di Kalimantan Tengah untuk Penguatan Akses terhadap Keadilan, 11 Juni 2013.

4 Kelompok Kerja Akses terhadap Keadilan - Kementerian Negara Perencanaan Pembangunan Nasional/BAPPENAS, Strategi Nasional Akses Terhadap Keadilan, Jakarta, 2009.

5 Ricardo Simarmata, "Merumuskan Peradilan Adat dalam Sistem Peradilan Nasional", Makalab disampaikan pada Seminar Merumuskan Kedudukan Peradilan Adat dalam Sistem Peradilan Nasional, diselenggarakan bersama oleh Perkumpulan HuMA dan Mahkamah Agung Republik Indonesia, Jakarta 10 Oktober 2013.

${ }^{6}$ Ahmadi Hasan, "Penyelesaian Sengketa Melalui Upaya Non Litigasi Menurut Peraturan Perundangundangan”, Jurnal AL-BANJARI, Vo. 5, No. 9, Januari - Juni, 2007.

${ }^{7}$ Edy Sanjaya, Hukum dan Putusan Adat dalam Praktek Peradilan Negara, http:/ / fakhukum.untagsmg.ac.id/ diakses tanggal 20 Pebruary 2017.

${ }^{8}$ Herlambang Perdana Wiratraman, Laporan Akbir Tim Pengkajian Hukum Tentang Peluang Peradilan Adat dalam Menyelesaikan Sengketa Antara Masyarakat Hukum Adat dengan Pibak Luar, Pusat Penelitian dan Pengembangan Sistem Hukum Nasional - BPHN, Kementerian Hukum dan HAM, Jakarta, 2013.

9 Tody Sasmita Jiwa Utama \& Sandra Dini Febry Aristya, "Kajian tentang Relevansi Peradilan Adat terhadap Sistem Peradilan Perdata Indonesia”, Mimbar Hukum, Volume 27, Nomor 1, February, 2015.

${ }^{10}$ Lilik Mulyadi, "Hukum dan Putusan Adat dalam Peradilan Negara", Makalah disampaikan dalam Dialog Nasional Bersama Perkumpulan HuMa dan Mahkamah Agung, Royal Kuningan, 10 Oktober 2013. 
masyarakat dalam kenyataannya masih hidup dan dimanfaatkan oleh masyarakat, hal ini merupakan fakta sosiologis yang sayangnya tidak mendapatkan pengakuan dalam politik hukum kekuasaan kehakiman. Tedy Sudrajat ${ }^{11}$ secara khusus melihat peranan hakim perdamaian desa sebagai wadah untuk mengakomodir kepentingan masyarakatnya dalam upaya menuju hukum yang progresif, sedangkan Trisno Rahardjo ${ }^{12}$ dengan menghadirkan studi kasus atas adat Banjar, Kalimantan Tengah, Aceh, Ambon, Lombok Utara, dan Flores - Nusa Tenggara Timur telah mengeksplorasi berbagai praktik mediasi pidana dalam ketentuan hukum pidana adat di masing-masing daerah. Studi ini menemukan adanya kesamaan model atas pelaksanaan mediasi atas kasus pidana dengan melibatkan pihak ketiga. Penyelesaian hukum atas kasus pidana ini menurutnya dapat menjadi dasar bagi proses mediasi modern, termasuk mediasi pidana yang dapat dituangkan dalam peraturan perundang-undangan.

Aceh sebagai situs penelitian, tampaknya memiliki daya tarik tersendiri bagi kalangan peneliti dari dalam maupun luar negeri untuk mengkajinya dalam berbagai aspek. Aceh sering disebut-sebut menjadi model untuk berbagai kebijakan pemerintah, misalnya saja, perdamaian atas konflik berkelanjutan, penerapan syariat Islam, pembuatan peraturan daerah (Qanun) dan bahkan pemilihan kepala daerah. Dalam bidang peradilan adat, Aceh juga tercatat menjadi model untuk provinsi lain tentang bagaimana mekanisme peradilan adat bisa melengkapi fungsi dari peradilan formal dalam memberikan akses terhadap keadilan, terutama bagi masyarakat miskin, rentan dan terpinggirkan. ${ }^{13}$ Dalam konteks Aceh, Mahdi ${ }^{14}$ dan Taqwaddin Husin ${ }^{15}$ membicarakan tentang eksistensi peradilan adat Gampong di Aceh. Juniarti ${ }^{16}$ secara khusus membahas arti penting

${ }^{11}$ Tedy Sudrajat, Aspirasi "Reformasi Hukum dan Penegakan Hukum Progresif Melalui Hakim Perdamaian Desa”, Jurnal Dinamika Hukum, Volume 10 No 3 Desember 2010, halaman 291 - 300.

12 Trisno Raharjo, Mediasi Pidana dalam Sistem Peradilan Pidana: Suatu Kajian Perbandingan dan Penerapannya di Indonesia, Buku Litera, Jogjakarta, 2011.

13 Baddruzzaman Ismail, Peradilan Adat sebagai Peradilan Alternatif dalam Sistem Peradilan di Indonesia (Peradilan Adat di Aceh). Edisi ke-2. Majelis Adat Aceh, Banda Aceh, 2015.

${ }^{14}$ Mahdi, "Eksistensi Peradilan Adat di Aceh", Hunafa: Jurnal Studia Islamika, Vol. 8 Nomor 2: Desember, 2011.

15 Taqwaddin Husin, "Penyelesaian Sengketa/Perselisihan Secara Adat Gampong di Aceh", dalam Kanun Jurnal Ilmu Hukum, No. 67, Tahun XVII (Desember, 2015), halaman 511 - 532.

${ }^{16}$ Juniarti, "Peran Strategis Peradilan Adat di Aceh dalam Memberikan Keadilan Bagi Perempuan dan Kaum Marjinal”, Conference Proceeding, Annual International Conference on Islamic Studies XII, Surabaya, 2012. 
dan peran strategis peradilan adat bagi perempuan dan kelompok marjinal lainnya dalam menyelesaikan sengketa-sengketa yang dihadapi, sedangkan Abidin ${ }^{17}$ dalam studinya mengajukan argumen bahwa keberadaan budaya, memberi andil penting dalam menyelesaikan konflik masyarakat. Penyelesaian konflik ini juga sebagai bagian dari upaya revitalisasi kearifan lokal di Aceh. Dalam dinamika politik Aceh, adat turut dikaji secara khusus. Studi yang dilakukan oleh beberapa peneliti lokal di Aceh menampilkan beragam tulisan terkait dengan revitalisasi adat di Aceh dengan mengambil studi kasus secara khusus di Aceh Besar, Nagan Raya dan Gayo. ${ }^{18}$

Dalam ranah hukum perdata khususnya pada bidang kewarisan, Syahrizal19 telah memberikan catatan refleksi atas integrasi hukum adat dengan hukum Islam. Menurutnya studi mendalam dan komprehensif terhadap inter-relasi hukum adat dan hukum Islam ternyata memperlihatkan hubungan yang sinergik-integratif. Hubungan ini didasarkan pada perpaduan prinsip-prinsip universal hukum kewarisan baik yang terdapat dalam hukum adat maupun hukum Islam. Melalui studi lapangan di Banda Aceh dan Aceh Besar, Arskal Salim ${ }^{20}$ juga telah mengeksplorasi praktek-praktek penyelesaian formal dan informal masalah pertanahan, kewarisan dan perwalian pasca tsunami. Penelitian ini menemukan bahwa kasus persengketaan hak atas tanah yang terkait erat dengan pasca tsunami tampaknya lebih sering diselesaikan di tingkat Gampong oleh pemuka adat. Hal ini dibuktikan dengan tidak adanya perkara-perkara dimaksud yang diajukan ke Pengadilan Negeri maupun Mahkamah Syar'iyah pada 2005.

Realitas penegakan hukum di Indonesia yang masih mengalami berbagai tantangan menjadi latar belakang studi ini. Cetak Biru Pembaruan Peradilan 2010 - 203521 telah mengidentifikasi beberapa permasalahan umum yaitu terkait dengan a) visi, misi dan organisasi lembaga peradilan, b) pelaksanaan fungsi teknis, c)

\footnotetext{
17 Abidin Nurdin, "Revitalisasi Kearifan Lokal di Aceh: Peran Budaya dalam Menyelesaikan Konflik Masyarakat", Journal Analisis, Volume XIII. Nomor 1. Juni, 2013.

${ }^{18}$ Lena Avonius \& Sehat Ihsan Shadiqin (ed), Adat dalam Dinamika Politik. Aceh. ARTI \& ICAIOS, Banda Aceh, 2010.

${ }^{19}$ Syahrizal, Hukum Adat dan Hukum Islam di Indonesia: Refleksi terhadap Beberapa Bentuk Integrasi Hukum dalam Bidang Kewarisan di Aceh, Yayasan Nadiya, Lhokseumawe, 2004.

20 Arskal Salim, "Praktek Penyelesaian Formal dan Infomal Masalah Pertanahan, Kewarisan dan Perwalian Pasca Tsunami di Banda Aceh dan Aceh Besar”, Laporan Penelitian, IDLO, Banda Aceh, 2006.

${ }^{21}$ Mahkamah Agung, Cetak Biru Pembaruan Peradilan 2010 - 2035, Jakarta, 2010
} 
upaya untuk meningkatkan kualitas kepemimpinan badan peradilan serta d) upaya untuk meningkatkan kredibilitas dan transparansi badan peradilan. Berdasarkan evaluasi yang dilakukan oleh Mahkamah Agung Republik Indonesia (MA) pada 2008, diketahui bahwa keberhasilan program dan capaian yang diperoleh MA baru mencapai 30\%. Organizational Diagnostic Assessment (ODA) pada 2009 menilai kinerja lembaga peradilan tetap mendapat sorotan dari berbagai kalangan, antara lain mengenai informasi proses peradilan yang tertutup, biaya berperkara yang tinggi, masih sulitnya akses masyarakat miskin dan terpinggirkan, serta proses penyelesaian perkara yang dirasakan masih sangat lama.

Sebagai salah satu media penyelesaian sengketa alternatif, eksistensi peradilan adat, salah satunya peradilan adat Gampong, merupakan langkah positif dalam mewujudkan keadilan di masyarakat. Konsep hukum adat dan peradilan adat sejatinya adalah akar keadilan restoratif. ${ }^{22}$ Dimana unsur utama dari keadilan restoratif yaitu adanya kerelaan dan partisipasi dari korban, pelaku serta masyarakat dalam melakukan perbaikan atas tindak pidana yang terjadi, yang juga menjadi ciri dari hukum adat. ${ }^{23}$ Selain hukum pidana, tentu hukum-hukum lain seperti pertanahan, perdata dan perkawinan yang ada dalam hukum adat sejatinya merupakan kristalisasi nilai-nilai keadilan yang hidup, tumbuh dan berkembang di masyarakat. Oleh karena itu, penelitian ini kemudian mencoba untuk menguraikan model penyelesaian sengketa dan peradilan adat di Aceh, yakni dengan memotret masyarakat Gampong beserta peradilan adatnya.

\section{Rumusan Masalah}

Studi ini akan mengkaji dua hal sebagai berikut. Pertama, bagaimanakah pandangan masyarakat Gampong di Aceh terhadap keberadaan peradilan adat? Kedua, bagaimanakah model penyelesaian sengketa yang digunakan oleh Majelis Peradilan Adat Gampong dan apa saja hal-hal yang mendasari pertimbangannya dalam menetapkan keputusan?

${ }^{22}$ Eva Achyani Zulfa, Keadilan Restoratif, Badan Penerbitan FHUI, Jakarta, 2009, hlm. 7 - 8 dalam Ahmad Ubbe, "Peradilan Adat dan Keadilan Restoratif", Jurnal Rechtsvinding, Volume 2 Nomor 2 Agustus 2013, hlm. 163

${ }^{23}$ Eva Achjani Zulfa, "Keadilan Restoratif Dan Revitalisasi Lembaga Adat di Indonesia", Jurnal Kriminologi Indonesia, Vol. 6 No. II Agustus 2010, hlm. 190 


\section{Tujuan Penelitian}

Seiring dengan rumusan masalah sebagaimana telah disampaikan di atas, maka studi ini bertujuan untuk mengeksplorasi pandangan masyarakat Aceh terutama masyarakat pada daerah Gampong tentang penerapan peradilan adat di Gampong. Selain itu, studi ini juga akan menggambarkan model-model penyelesaian sengketa yang digunakan oleh Majelis Peradilan Adat Gampong dan hal-hal yang mendasari pertimbangannya dalam menetapkan keputusan. Terakhir, studi ini akan memberikan gambaran terhadap penghematan anggaran penegakan hukum melalui jalur peradilan formil dengan memanfaatkan lembaga peradilan adat di Gampong.

\section{Metode Penelitian}

Penelitian ini merupakan penelitian kualitatif, dengan menggunakan pendekatan sosio-legal yang berasumsi bahwa hukum adat dan praktek penyelesaian sengketa melalui peradilan adat kiranya sudah dapat menjadi pemain utama dalam mengatasi peningkatan jumlah sengketa di masyarakat serta membuka akses keadilan khususnya bagi masyarakat miskin dan kelompok marginal lainnya yang kesulitan untuk mengakses lembaga peradilan. Lebih dari itu, penelitian terhadap hukum adat menjadi bagian yang sangat penting dalam rangka pembinaan hukum nasional, terutama jika dikaitkan dengan bidang hukum yang sensitif serta anggaran penegakan hukum. Data dalam penelitian ini diperoleh melalui penelitian kepustakaan dan penelitian lapangan. Penelitian bibliografi dilakukan dengan merujuk pada sejumlah buku, artikel, jurnal, laporan penelitian, serta peraturan perundang-undangan.

Penelitian empiris dilakukan dengan melakukan pengamatan langsung atas praktek-praktek penyelesaian secara adat serta mewawancarai geuchik, orang tua desa, para pihak bersengketa untuk mengeksplorasi pandangannya terkait dengan model-model penyelesaian sengketa secara adat yang dipraktekkan oleh masyarakat serta pertimbangan-pertimbangan hukum yang dipergunakannya dalam memutus sengketa. Wawancara kepada aparatur kepolisian, kejaksaan dan hakim pengadilan juga dilakukan untuk mendapatkan gambaran terkait dengan 
pandangan masing-masingnya atas realitas pelaksanaan peradilan adat serta mendiskusikan kemungkinan penghematan anggaran penegakan hukum.

\section{Hasil Penelitian dan Pembahasan}

\section{Peradilan Adat dalam Pandangan Masyarakat Gampong Aceh}

Orang Aceh meyakini bahwa ketertiban dan kedamaian dalam masyarakat itu dapat dijaga dengan menjaga adat. Hal ini dapat ditunjukkan melalui Narit Maja Aceh atau adagium yang secara turun temurun diwarisi dan diyakini oleh orang Aceh yang menyatakan "Ta pageu lampoeh ngon kawat, ta pageu nanggroe ngon adat", pepatah ini diartikan sebagai berikut "kita mengamankan kebun dengan kawat, kita mengamankan negeri dengan adat". Untuk itu, dalam merealisasikan penegakan hukum adat dalam menghadapi berbagai kasus dan sengketa yang ada di masyarakat pada tingkat Gampong dan Mukim, maka pemerintah melalui Pasal 6 Undang-Undang Nomor 44 Tahun 1999 serta Pasal 98 Undang-Undang Nomor 11 Tahun 2006 telah memberikan penguatan atas keberadaan lembaga adat di Aceh. Dua instrumen hukum tersebut menyatakan bahwa lembaga adat berfungsi dan berperan sebagai wahana partisipasi masyarakat dalam penyelenggaraan pemerintahan Aceh dan pemerintahan kabupaten/kota di bidang keamanan, ketenteraman, kerukunan, dan ketertiban masyarakat.

Pada keempat wilayah penelitian, kami memperhatikan masyarakat telah mengetahui dan memahami bahwa setiap sengketa atau perselisihan dapat diselesaikan di tingkat Gampong. Hal ini ditunjukkan secara khusus oleh informan-informan yang kami temui, yang rata-rata berusia remaja sampai dengan dewasa dan manula. Mereka memahami bahwa setiap sengketa yang terjadi diantara warga masyarakat khususnya atas 18 perkara yang telah mendapatkan pengaturan dalam Qanun Nomor 8 Tahun 2008, ${ }^{24}$ dapat diajukan penyelesaiannya melalui lembaga adat. Beberapa informan bahkan dapat menjelaskan dengan pasti jenis-jenis sengketa yang dapat diselesaikan melalui peradilan adat khususnya di tingkat Gampong dan bagaimana praktek penyelesaian sengketa dilakukan serta aktor-aktor yang terlibat. Pemahaman ini dipengaruhi oleh beberapa hal

${ }^{24}$ Lihat lebih lanjut dalam Qanun Aceh Nomor 8 Tahun 2008 tentang Pembinaan Kehidupan Adat dan Adat Istiadat. 
diantaranya adalah, sosialisasi yang dilakukan pemerintah yang bagi banyak kalangan masyarakat dianggap cukup menyeluruh dan menjangkau hampir semua lapisan masyarakat dan disampaikan dalam berbagai bentuk atau media sosialisasi. Di Lhokseumawe sebagai contoh, Pemerintah Kota bekerjasama dengan Kepolisan Resor Lhokseumawe telah menayangkan sosialisasi melalui media baliho berukuran besar yang dipasang pada beberapa titik sentral dan strategis sehingga dapat diakses secara langsung oleh masyarakat dan menjadi media edukasi. Sosialisasi ini dilakukan secara kontinyu dan berkesinambungan dan diikuti dengan berbagai kegiatan penguatan bagi aparatur Gampong dan mukim dalam melaksanakan peradilan adat ${ }^{25}$.

Walaupun dinilai belum efektif, namun upaya penguatan dimaksud juga dilakukan dalam bentuk pelatihan-pelatihan dikoordinir oleh Majelis Adat Aceh tingkat Kabupaten/Kota tentang penyelenggaraan peradilan di tingkat Gampong dan mukim. Kegiatan pelatihan ini merujuk pada Pedoman Peradilan Adat di Aceh yang diterbitkan oleh Majelis Adat Aceh. Hal lain yang tidak kalah membawa pengaruh besar adalah keyakinan orang Aceh - khususnya masyarakat di tingkat Gampong, bahwa mekanisme penyelesaian sengketa melalui peradilan adat lebih dapat terjangkau tidak hanya dari segi jarak tempuh namun juga dari segi biaya yang harus disiapkan oleh para pihak bersengketa, dan menjadi sebaik-baiknya penyelesaian $^{26}$. Bagaimana mereka yakin dan percaya? Masing-masing informan mengungkapkan dalam ekspresi yang berbeda. Bagi sebagian besar informan yang kami wawancarai, khususnya warga masyarakat dari golongan dewasa dan manula rata-rata mengekspresikan dalam bentuk pernyataan dan refleksi atas pentingnya menjaga persaudaraan dan silaturahmi. Referensi yang mereka gunakan adalah ketentuan-ketentuan agama Islam yang menyerukan perdamaian. Selain itu, narit maja Aceh juga disampaikan untuk memberikan gambaran kepercayaan mereka atas mekanisme peradilan adat. Melalui wawancara dan kegiatan FGD, ${ }^{27}$ kami mendengarkan informan menuturkan beberapa narit maja

${ }^{25}$ Dalam pengamatan penulis, media sosialisasi ini ditayangkan oleh Pihak Pemerintah Kota Lhokseumawe beserta Polres Lhokseumawe selama kurun waktu lebih dari 1,5 tahun.

${ }^{26}$ Wawancara dengan Zainuddin - Geuchik Suak Raya, Meulaboh, 29 Agustus 2017; Tgk. H. Sayuti Syuib (Anggota MPU Meulaboh), 29 Agustus 2017; Tgk. Armia (Anggota Tuha Peut Lhokseumawe), 5 Juni 2017.

${ }^{27}$ Kegiatan Focus Group of Discussion (FGD) diselenggarakan di Lhokseumawe, tanggal 18 Agustus 2017; di Tapak Tuan Tanggal 28 Agustus 2017 dan di Meulaboh tanggal 29 Agustus 2017, dengan mengundang perwakilan 
berikut: "adat ban adat, hukom ban hukum. adat ngon hukom si judo dua tatkala meusapat adat ngon hukum Nanggroe senang hana goda" yang artinya "adat menurut adat, hukum menurut hukum, adat dengan hukum sama kembar; ketika adat bermufakat dengan hukum, (maka) negeri (akan) senang tiada huru-hara. Namun demikian perlu diperhatikan dan menjadi pertimbangan, jangan sampai terjadi dengan hukuman itu masyarakat atau para pihak bersengketa khususnya menjadi pecah/bermusuhan sehingga dapat merusak kerukunan masyarakat di lingkungannya.

Dalam menyelesaikan sengketa yang diajukan kepada aparatur Gampong, masing-masing aparatur memperhatikan asas-asas penyelesaian sengketa. Majelis Adat Aceh (MAA) sendiri telah menghimpun asas-asas yang selama ini telah diterapkan oleh masyarakat Gampong dalam menyelesaikan sengketa. Asas dimaksud adalah asas amanah atau terpercaya, asas akuntabilitas atau bertanggung jawab, asas non-diskriminasi yang dikenal juga dengan asas kesetaraan di depan hukum, asas cepat, mudah dan murah, asas ikhlas dan sukarela, asas kerukunan atau penyelesaian secara damai, asas musyawarah untuk mufakat, asas keterbukaan untuk umum, asas jujur dan kompetensi, asas menghargai keberagaman, asas praduga tak bersalah dan asas berkeadilan ${ }^{28}$.

Dibandingkan daerah lain, dengan dukungan pranata peraturan di tingkat daerah serta segala keistimewaan yang dimiliki kiranya posisi Aceh memiliki peluang lebih besar untuk terus dapat menjaga keberlangsungan upaya pelestarian atas hukum adat dan peradilan adat, namun demikian tidak dapat dipungkiri bahwa disamping adanya sebagian masyarakat yang meyakini mekanisme penyelesaian sengketa ini, modernisasi dengan dampak negatifnya turut membawa dampak yang melemahkan upaya pelestarian dimaksud. Wawancara yang kami lakukan, menemukan alasan penolakan untuk memanfaatkan peradilan Gampong adalah adanya anggapan yang berkembang di masyarakat terhadap ketidakpastian hukum yang menunjukkan kondisi pluralisme hukum yang

dari Majelis Adat Aceh (MAA), Majelis Permusyawaratan Ulama (MPU), Polres, Kejaksaan Negeri, Pengadilan Negeri, Mahkamah Syaríyah serta aparatur Tuha Peut Kampung dari masing-masing Kota dan Kabupaten tersebut. ${ }^{28}$ Lihat Lebih lanjut pada MAA, Pedoman Peradilan Adat Aceh - Untuk Peradilan Adat Yang Adil dan Kompatibel, Nanggroe Aceh Darussalam, 2008, hlm. 5 - 6. 
lemah $^{29}$ atas putusan dimaksud serta ketidakpercayaan secara personal kepada aparatur hakim adat. Ketidakpastian atas putusan dimaksud dipahami oleh masyarakat karena tidak adanya Qanun khusus di tingkat Gampong yang memberikan pengaturan, oleh karenanya tuntutan masyarakat kepada aparatur Gampong untuk menetapkan Qanun Gampong ini juga tinggi. ${ }^{30}$ Tuntutan senada dari Gampong Keupok Nibong di Aceh Utara juga terjadi, sampai akhirnya dengan tujuan untuk menjaga dan mengatur serta memperbaiki masalah sosial yang banyak terjadi di lingkungan masyarakat Keupok Nibong, maka unsur pemuka Gampong melalui Geuchik menetapkan Qanun Gampong tentang Hukum Keluarga (Ahwal al Syakhsyiyah). Qanun ini secara khusus memberikan pengaturan atas perkawinan, mulai dari tahapan pra nikah, akad nikah dan walimah, juga mengatur tentang thalak, fasakh dan ruju', pembagian harta bersama dan mawaris, dan juga diatur tentang penyelesaian sengketa. ${ }^{31}$

Kami menjumpai beberapa kasus yang oleh para pihak bersengketa diajukan perkaranya langsung kepada aparatur kepolisian, ${ }^{32}$ misalnya saja kasus pencemaran nama baik di Lhokseumawe, perkara sweeping dugaan khalwat yang berujung pada tindakan penganiayaan di Aceh Utara serta sengketa waris antar keluarga kakak beradik yang berujung pada penganiayaan di Pidie. Ketiga sengketa ini masuk dalam kategori jenis sengketa/perselisihan yang harusnya dapat diselesaikan secara adat merujuk pada ketentuan Pasal 13 Qanun Aceh Nomor 9 Tahun 2008 tentang Pembinaan Adat. 18 jenis sengketa/perselisihan yang dapat diselesaikan secara adat, meliputi: (1) Perselisihan dalam rumah tangga, (2) Sengketa antara keluarga yang berkaitan dengan faraidh, (3) Perselisihan antar warga, (4) Khalwat/ mesum, (5) Perselisihan tentang hak milik, (6) Pencurian dalam

${ }^{29}$ Lihat juga Arskal Salim, "Pluralisme Hukum di Indonesia: Keberadaan Hukum Islam dalam Peraturan Perundang-Undangan Indonesia”, HARMONI Jurnal Multikultural dan Multireligius, Volume VII, No. 28, Oktober - Desember, 2008.

${ }^{30}$ Wawancara dengan Tgk Armia (Anggota Tuha Peut Gampong Keude Aceh, Lhokseumawe), 2 Juni 2017; wawancara dengan Zainal Abidin (Geuchik Gampong Keupok Nibong, Aceh Utara) 10 Juni 2017; wawancara dengan Zainuddin (Geuchik Gp Suak Raya, Meulaboh) 29 Agustus 2017.

${ }^{31}$ Informasi ini kami dapatkan melalui kegiatan Focus Group of Discussion (FGD) dengan aparatur gampong di Gampong Keupok Nibong, Aceh Utara, tanggal 10 Juni 2017. Peserta FGD terdiri dari Geuchik Gampong (Zainal Abidin), Mukim (Zainal Abidin), Anggota Tuha Peut, Imeum Mesjid (Tgk. H. Abdul Rasyid), Imeum Gampong (Tgk. Rusli), Kepala KUA Nibong dan MAA Kec Nibong (Tgk. Saifuddin, beliau juga mantan anggota $\mathrm{MPU})$.

32 Wawancara dengan Sarimin, (Anggota Polres Lhokseumawe), tanggal 7 Agustus 2017; Iptu Wahyudi (Kanit Reskrim, Polsek Samudera), tanggal 22 Agustus 2017. 
keluarga, (7) Perselisihan harta sehareukat, (8) Pencurian ringan, (9) Pencurian ternak peliharaan, (10) Pelanggaran adat tentang ternak, pertanian, dan hutan, (11) Persengketaan di laut, (12) Persengketaan di pasar, (13) Penganiayaan ringan, (14) Pembakaran hutan (dalam skala kecil yang merugikan komunitas adat), (15) Pelecehan, fitnah, hasut, dan pencemaran nama baik, (16) Pencemaran lingkungan (skala ringan), (17) Ancam mengancam (tergantung dari jenis ancaman), dan (18) Perselisihan-perselisihan lain yang melanggar adat dan adat istiadat.

Pasal 13 ayat (2) Qanun tersebut lebih lanjut menegaskan bahwa penyelesaian sengketa/perselisihan adat dan adat istiadat sebagaimana dimaksud di atas diselesaikan secara bertahap. Sedapat mungkin, perkara-perkara sebagaimana dimaksudkan di atas, diselesaikan terlebih dahulu pada tingkat peradilan Gampong, tidak langsung dibawa keluar Gampong untuk menyelesaikan kasuskasus di atas. Bahkan, dalam Pasal 13 ayat (3) Qanun tersebut ditegaskan lagi, bahwa aparat penegak hukum memberikan kesempatan agar sengketa/perselisihan diselesaikan terlebih dahulu secara adat di Gampong. Penyelesaian sengketa dalam peradilan adat tidak termasuk dalam tindak pidana berat. Berkaitan dengan hal tersebut telah diterbitkan Surat Keputusan Bersama (SKB) antara Gubernur Aceh dengan Kepolisian Daerah Aceh dan Majelis Adat Aceh (MAA) melalui Nomor SKB sebagai berikut: 189/677/2011, 1054/MAA/XII/2011, B/121/I/2012 tentang Penyelenggaraan Peradilan Adat Gampong dan Mukim atau nama lain di Aceh. Keputusan bersama ini juga memberikan penekanan kepada aparatur kepolisian untuk memberikan kesempatan agar setiap sengketa/perselisihan sebagaimana dimaksud dalam diktum kesatu untuk diselesaikan terlebih dahulu melalui peradilan adat Gampong dan mukim atau nama lain di Aceh.

Untuk memberikan gambaran realitas atas pelaksanaan penyelesaian sengketa sebagaimana diatur dalam Pasal 13 Qanun No. 8 Tahun 2008, maka pada bagian berikut akan disampaikan satu dari sekian kasus perselisihan antar warga yang kerap terjadi di Aceh dan mendapatkan penyelesaiannya melalui mekanisme peradilan adat di Gampong. Perselisihan bermula dari amarah salah seorang warga berinisial M (Pemilik Nursery and Gardening) warga Gampong Padang Sakti, 
Kecamatan Muara Satu Kota Lhokseumawe kepada warga Gampong Paloh, berinisial PN dikarenakan salah satu lembu piaraan PN menyenggol pot bunga milik $\mathrm{M}$ dan pecah. Amarah $\mathrm{M}$ diungkapkan dengan caci maki kepada PN dan menyebabkan "berantam mulut". Perselisihan memuncak ketika IH (anak menantu dari PN) mendengar perselisihan ini dan merasa tidak terima dikarenakan mertuanya dicaci maki oleh orang yang jauh lebih muda. Dalam pandangan keluarga PN sendiri, pecahnya pot bunga milik M tidak sepenuhnya kesalahan dari pihak PN karena tidak menjaga lembu miliknya. Karena posisi pot bunga dimaksud tidak ditempatkan di areal usaha $\mathrm{M}$ namun berada di kawasan lapangan, tempat biasa warga gampong sekitar melepaskan lembu piaraan mereka untuk makan rumput. Dikarenakan ketidaksukaan ini, maka IH mendatangi langsung $\mathrm{M}$ dan menyatakaan keberatannya atas caci maki dimaksud dan meminta M untuk segera meminta maaf kepada mertuanya. Namun pada saat kejadian ini, M melakukan pemukulan awal kepada IH dan segera dibalas langsung dan terjadi baku pukul yang menyebabkan luka pada bagian hidung M. Pada pihak IH sendiri tidak mengalami luka ataupun memar berlebihan. Atas peristiwa ini, pihak $\mathrm{M}$ segera melaporkan kejadian perkara kepada Polsek setempat dengan membawa Surat Keterangan dari Rumah Sakit dan menuntut pembayaran ganti rugi sejumlah uang tertentu. Mendengar pelaporan ini, Pihak IH juga melakukan pelaporan serupa kepada pihak Gampong Padang Sakti dan juga Polsek setempat dengan mengajukan keterangan bahwa 1) telah terjadi peristiwa tidak menyenangkan yang dilakukan oleh M kepada PN - Mertua IH, dan 2) pemukulan yang dilaporkan oleh M kepada IH juga dilaporkan kembali, dan 3) menuntut penyelesaian sengketa dilakukan. 33

Memperhatikan kedua laporan ini, kemudian pihak Polsek berkoordinasi kepada aparatur gampong Padang Sakti dan mengarahkan pihak aparatur untuk menyelesaikan terlebih dahulu oleh Gampong dengan melibatkan kedua gampong Padang Sakti dan Gampong Paloh. Amanat ini diberikan sejalan dengan ketentuan Pasal 13 ayat (3) Qanun No. 8 Tahun 2008 sebagaimana telah dinyatakan di atas.

\footnotetext{
${ }^{33}$ Informasi terkait dengan peristiwa ini, Penulis dapatkan melalui wawancara kepada IR (istri IH) dan salah seorang warga Gampong Padang Sakti (NN).
} 
Studi ini meyakini bahwa pengakuan terhadap praktek-praktek penyelesaian sengketa melalui peradilan adat serta adanya dukungan payung hukum atas pelaksanaannya melalui beragam peraturan perundang-undangan, dengan menghadirkan praktek-praktek yang telah dilakukan oleh Aceh sebagai contoh akan menunjukkan situasi bekerjanya hukum. Hukum yang mencerminkan keseimbangan antara sisi kepastian, keadilan dan kemanfaatan dikarenakan mekanisme peradilan adat yang dinamis membawa makna penting secara sosiologis. Bagi masyarakat Aceh sendiri hukum adatnya adalah hukum Islam. Sebagaimana hadih maja yang menyatakan adat ngon agama lagee zat ngon sifeut, filosofi ini dimaknai bahwa, keduanya - adat dalam prakteknya dengan pengamalan agama Islam - tidak dapat dipisahkan.

\section{Model Penyelesaian Sengketa dan Pertimbangan yang Digunakan Majelis Peradilan Adat Gampong}

Pada bagian berikut dari tulisan ini akan mengeksplorasi model atau pola penyelesaian sengketa yang dilakukan oleh Gampong terhadap perselisihan yang terjadi di masyarakat, khususnya pada wilayah kota Lhokseumawe, Kabupaten Aceh Utara, Kabupaten Aceh Barat dan Tapak Tuan. Sekaligus memaparkan caracara yang dilakukan oleh Geuchik Gampong atau hakim adat dalam menggali referensi untuk menyusun pertimbangan hukum serta menetapkan putusannya. Selama durasi penelitian ini berlangsung, dan berdasarkan wawancara, diskusi terfokus serta observasi pada praktek-praktek penyelesaian sengketa secara adat yang dilakukan oleh masyarakat Aceh, ${ }^{34}$ didapatkan informasi bahwa terdapat 2 model atau pola utama pelaksanaan peradilan adat. Pertama, model atau praktek penyelesaian sengketa yang paling sederhana dan praktek ini diakui sebagai tradisi yang turun temurun masih terus dipergunakan oleh masyarakat. Keterlibatan para pihak biasanya terbatas, yaitu para pihak yang bersengketa serta Geuchik sendiri atau dalam hal dibutuhkan Geuchik - misalnya untuk menggali referensi-referensi serta pertimbangan hukum yang harus diambil, maka Geuchik akan melibatkan Tengku Imuem (pemuka agama) dan diselenggarakan dalam durasi waktu yang

\footnotetext{
34 Penelitian lapangan dengan melakukan wawancara, observasi dan FGD untuk penelitian ini dilakukan sepanjang tahun 2016 dan 2017; Sebagian kegiatan FGD diantaranya diselenggarakan di Lhokseumawe, tanggal 18 Agustus 2017; di Tapak Tuan Tanggal 28 Agustus 2017 dan di Meulaboh tanggal 29 Agustus 2017.
} 
relatif singkat. Peranan Geuchik sebagai pemangku adat dan pemimpin kampung lebih menonjol dan sifat keaktifannya juga lebih besar. Tidak jarang Geuchik akan melakukan kunjungan-kunjungan ke rumah masing-masing pihak bersengketa untuk mencari informasi detil tentang permasalahan yang ada. Tindakan ini merupakan upaya yang dilakukan dengan maksud untuk menurunkan tingkat ketegangan atas sengketa yang dihadapi oleh para pihak serta sebagai bentuk negosiasi yang coba dibangun oleh Geuchik untuk mendapatkan kesepakatan perdamaian. Ketika Geuchik telah mendapatkan informasi yang dirasa cukup dari kedua belah pihak atas duduk perkaranya, kemudian para pihak akan diundang untuk bertemu secara langsung. Lokasi pertemuan bersifat fleksibel, dan tidak jarang rumah Geuchik dipilih sebagai tempat yang paling netral selain juga tentunya meunasah maupun mesjid di Gampong turut menjadi alternatif utama.

Model kedua, adalah pelaksanaan peradilan adat yang "menyerupai" persidangan formil. Pelaksanaannya dinilai lebih sistematis dan merujuk pada Pedoman Peradilan Adat yang diterbitkan oleh Majelis Adat Aceh. ${ }^{35}$ Selain para pihak yang bersengketa, dalam pelaksanaan peradilannya memiliki struktur tertentu yaitu adanya Geuchik sebagai ketua majelis peradilan, dan Tuha Peut Gampong, Imuem Meunasah dan Ulama, Cendikiawan, serta Tokoh Adat lainnya sebagai anggota. Formasi ini dilengkapi oleh Panitera yang dijabat oleh Sekretaris Gampong yang memiliki peranan sebagaimana panitera pada persidangan yaitu mencatat jalannya agenda sidang dalam berita acara persidangan. Dalam penyelesaian perkara yang dipandang berat dan melibatkan lebih banyak orang, misalnya perselisihan antar warga ataupun perselisihan di pasar maka proses peradilan akan mengambil tempat di kantor Geuchik atau di Meunasah. Biasanya agenda persidangan akan dibuka secara resmi oleh Geuchik, dan kerap kali dihadiri oleh masyarakat sekitar. Pada perkara perselisihan antar warga M vs IH sebagaimana yang telah diuraikan pada sub bab sebelumnya, maka model penyelesaian seperti inilah yang dilakukan oleh aparatur gampong. Sidang dilakukan lebih kurang empat kali dalam ingatan IH. Pada tahap pertama, pihak Hakim Peradilan Adat telah berupaya untuk melakukan upaya persuasif kepada

${ }^{35}$ MAA, Pedoman Peradilan Adat..., Op.Cit. 
masing-masing pihak, bahkan pihak PN, IH dan keluarga juga menjenguk M ke Rumah Sakit namun tidak diterima dengan baik oleh pihak M maupun keluarga besarnya. Kemudian, pada tahap kedua, kedua belah pihak diundang secara resmi oleh Hakim Peradilan Adat Gampong untuk didengarkan keterangannya di hadapan sidang peradilan adat yang mengambil tempat di Meunasah Gampong. Pada tahap ini, masing-masing pihak diberikan kesempatan oleh Hakim Peradilan Adat untuk menyampaikan keluhan dan laporannya, dan setelah mendengarkan kedua belah pihak, hakim peradilan adat beserta aparatur meminta kesediaan dari para pihak untuk berdamai saja, namun tawaran perdamaian ini secara serta merta ditolah oleh pihak $\mathrm{M}$ dengan alasan dirinya yang mengalami luka lebih serius daripada IH maupun PN. M melaporkan bahwa dirinya mengalami patah tulang hidung dan membutuhkan banyak biaya untuk proses pengobatan. Untuk menguatkan dalilnya, Pihak M juga menghadirkan Surat Keterangan Dokter dari RS.

Tahap berikutnya, yaitu tahap ketiga lebih kurang merupakan tahap pembuktian dan pendalaman atas sengketa yang berlangsung. Pada tahap ini sebagaimana tahap-tahap sebelumnya, Majelis Hakim pada peradilan adat di gampong tetap menghimbau kepada masing-masing pihak untuk ishlah atau berdamai saja dan tidak melarut-larutkan permasalahan ini, terutama dengan mempertimbangkan bahwa sengketa terjadi antara dua warga yang bersebelahan gampong. Pada proses pembuktian ini, pihak hakim peradilan adat menemukan keterangan dari Rumah Sakti bahwa tidak benar terjadi patah tulang hidung sehingga argumen kerugian yang diajukan oleh pihak $\mathrm{M}$ tidak terbukti.

Selanjutnya, pada tahap keempat dari proses persidangan secara adat ini, selain memperhatikan bukti-bukti yang muncul selama proses berlangsung, pihak aparatur gampong juga menelusuri track record masing-masing pihak terutama dari aspek hubungan kemasyarakatan keduanya. Menurut pihak aparatur gampong, mengkaji hubungan kemasyarakatan yang dimiliki masing-masing pihak adalah penting untuk menentukan penyelesaian sengketa diantara keduanya. Jika masingmasingnya memiliki hubungan kemasyarakatan yang baik dengan sesama warga dan aktif mengikuti kegiatan-kegiatan di gampong serta rutin mengikuti aktifitas keagaaman di gampong seperti sholat berjamaah dan lain sebagainya maka kepada 
para pihak dikuatkan untuk penyelesaian damai tanpa ada sanksi, namun jika ternyata salah satu pihak atau keduanya tidak memenuhi standar gampong sebagaimana di atas, maka kepada keduanya akan diberikan arahan serta penguatan untuk aktif dan berpartisipasi di gampong sehingga mengurangi konflik yang ada. Kasus ini diputuskan dengan perdamaian antara kedua belah pihak, tanpa ada pembebanan pembayaran ganti rugi antara keduanya. Sebagai tanda pengikat perdamaian kepada kedua belah pihak diminta untuk memberikan sedeqah kepada Meunasah Gampong dan mengadakan khandury bersama.

Memperhatikan beragam penyelesaian sengketa yang terjadi di masyarakat, kami mencatat ada praktek baik yang dilakukan oleh Pemerintah Kota Lhokseumawe melalui MAA dalam hal pendokumentasian berita acara pelaksanaan peradilan melalui pencatatan ini. Untuk setiap Gampong yang telah berhasil mendamaikan para pihak bersengketa dan membuat berita acara penyelesaiannya dapat mengajukan ganti biaya administrasi kepada pihak MAA Lhokseumawe dengan besaran biaya penggantian lebih kurang Rp. 300.000,00, yang pengalokasiannya dimaksudkan untuk membina Gampong, namun sayangnya program ini tidak kontinyu dengan alasan tidak tersedianya anggaran pada Daftar Isian Penggunaan Anggaran MAA Lhokseumawe.

Kedua pola atau model utama ini dapat dijumpai hampir di semua daerah di Aceh dengan penamaan yang menyesuaikan dengan kondisi di masing-masing daerah sesuai dengan ciri khas daerahnya. Penting untuk ditambahkan bahwa keberadaan para pemimpin adat sebagaimana disampaikan di atas memiliki beberapa tanggung jawab, yaitu pertama, menyelenggarakan proses peradilan adat dalam setiap tahapannya, dimulai dari menerima laporan, memeriksa duduk persoalan sampai dengan tahap pengambilan putusan. Kedua, menjatuhkan putusan dengan adil dengan didasarkan pada bukti-bukti yang dapat dipertanggungjawabkan serta memenuhi rasa keadilan para pihak. Ketiga, melindungi hak-hak para pihak bersengketa dalam setiap tahapan prosesnya, termasuk mendengarkan secara berimbang. Keempat, mencatat proses dan keputusan peradilan adat secara akurat dan memenuhi prinsip pendokumentasian dan administrasi. Terakhir, kelima - tanggung jawab pemangku adat adalah untuk mengarsipkan berkas perkara dengan baik dan aman. Fungsi pengarsipan ini 
adalah sebagai data dukung dalam hal terjadinya pengulangan sengketa atau perselisihan, maka pemangku adat memiliki bukti dan referensi dalam melakuka peradilan serta mengambil keputusan.

Ketika perselisihan dan sengketa antara kedua belah pihak telah mendapatkan titik temu, maka menurut praktek adat yang berlaku di Aceh, para pihak akan didamaikan. Proses ini dikenal dengan istilah peudame (melakukan perdamaian atau berdamai), suloh (jalan damai atau perdamaian antara dua individu yang berselisih tetapi tidak sampai berdarah), diet (sejenis perdamaian dengan unsur ganti disertai dengan peusijuek), serta sayam dan peusijuek (sejenis perdamaian antar pihak/kelompok masyarakat/antar Gampong yang bertikai dalam hal mana para pihak bersengketa menjadi korban dan mengeluarkan darah. Setelah peusijuek selesai maka dilanjutkan dengan prosesi peumat jaroe (saling berjabat tangan) antara pihak yang bersengketa. Kegiatan ini dilakukan (difasilitasi) oleh keuchik, teugku imuem dan tertua adat. Peumat jaroe merupakan simbol perbaikan hubungan antara para pihak yang bersengketa, dengan harapan konflik antar mereka dapat segera berakhir. Oleh karena itu, dalam proses peumat jaroe, pihak yang memfasilitasi mengucapkan kata-kata khusus seperti: "Nyoe kasep oh no bek na dendam le, nyoe beujeut keu jalinan silaturahmi, karena nyan ajaran agama geutanyoe". (artinya, masalah ini sudah cukup sampai disini dan jangan diperpanjang lagi, bersalaman ini diharapkan menjadi awal jalinan silaturahmi, sebab ini ajaran agama kita ${ }^{36}$.

Pada saat FGD Penguatan Majelis Peradilan Adat Gampong ${ }^{37}$ yang dihadiri oleh Geuchik Gampong, Tuha Peut, Imam Gampong serta Mukim dan perwakilan Lembaga Swadaya Masyarakat dan Lembaga Bantuan Hukum Pos Lhokseumawe dan LBH APIK Aceh, kami menjumpai informasi bahwa penyelenggaraan peradilan adat yang merujuk pada praktek-praktek yang telah berlangsung selama ini di masyarakat dan juga mendasarkan pada Qanun Lembaga Adat dilakukan oleh lembaga Gampong, dan dalam hal sengketa tidak mendapatkan penyelesaian

${ }^{36}$ Mahmudin., et.al, "Nilai Lokal dan Konflik Aceh: Studi Dimensi Budaya Dalam Penguatan Civil Society”, Laporan Penelitian, Satker BRR Revitalisasi dan Pengembangan Kebudayaan NAD, Banda Aceh, 2006; Lihat juga Syahrizal, Mediasi Dalam Hukum Syariah, Hukum Adat dan Hukum Nasional, Kencana, Jakarta, 2011.

${ }^{37}$ FGD pada tanggal 18 Agustus 2017, di Lhokseumawe, 
di tingkat Gampong, maka Mukim memiliki kewenangan untuk menyelesaikannya. Dalam pelaksanaan peradilan adat di tingkat Gampong maupun mukim, diakui masih belum optimal dikarenakan beberapa hal seperti kurangnya pemahaman geuchik dan aparatur Gampong lainnya terhadap mekanisme maupun substansi permasalahan yang disengketakan maupun mekanisme peradilan yang harus ditempuh. Figur Geuchik dan gaya komunikasi Geuchik yang dinilai tidak arif, serta kurangnya rasa percaya masyarakat atas keputusan yang ditetapkan oleh majelis perdamaian di Gampong juga memberi andil terhadap lemahnya pelaksanaan peradilan adat, 38 namun demikian, kondisi ini tidak menyebabkan berhentinya praktek-praktek penyelesaian sengketa dimaksud.

\section{Penutup}

Dari pembahasan di atas, dapat disimpulkan, pertama, keberadaaan peradilan adat di Gampong dipandang oleh masyarakat sebagai alternatif awal dan memiliki potensi positif ditengah semakin banyaknya masalah berupa pelanggaran ringan yang bisa diatasi oleh masyarakat tanpa harus pergi ke aparat penegak hukum. Adanya peradilan adat tidak hanya meringankan beban tugas pengadilan dan mengurangi akumulasi kasus, namun juga membantu warga negara mengakses perlindungan hak mereka.

Kedua, terdapat 2 model penyelesaian sengketa yang lazim diberlakukan masyarakat di gampong-gampong di Aceh sampai dengan saat ini, model pertama adalah model penyelesaian sengketa yang sederhana dengan keterlibatan Geuchik yang sangat aktif untuk menyelesaikan sengketa diantara masyarakat, model kedua adalah pelibatan unsur Tuha Peut Gampong secara keseluruhan untuk menyelesaikan sengketa dan pola penyelesaiannya juga dilakukan dengan model menyerupai persidangan formil dan merujuk kepada pedoman peradilan adat yang diterbitkan oleh Majelis Adat Aceh.

Negara harus berpikir untuk menerapkan sistem hukum adat ini secara menyeluruh, tidak hanya di Aceh, namun juga di daerah-daerah lain di Indonesia.

38 Wawancara dengan Abdullah (Ketua MAA Kecamatan Simpang Kramat); Lukman (Imuem Mukim Kecamatan Simpang Kramat); dan Munawwir, (Geuchik Gampong Tanjong Baroh Kecamatan Samudera), tanggal 5 Mei 2017. 
Sehingga upaya untuk mewujudkan pluralisme hukum yang kuat dalam sistem hukum Indonesia dapat terwujud.

\section{Daftar Pustaka}

\section{Buku}

Avonius, Lena \& Sehat Ihsan Shadiqin (ed), Adat dalam Dinamika Politik Aceh, ARTI \& ICAIOS, Banda Aceh, 2010.

Ismail, Baddruzzaman, Peradilan Adat sebagai Peradilan Alternatif dalam Sistem Peradilan di Indonesia (Peradilan Adat di Aceh), Edisi ke-2. Majelis Adat Aceh, Banda Aceh, 2015.

Raharjo, Trisno, Mediasi Pidana dalam Sistem Peradilan Pidana: Suatu Kajian Perbandingan dan Penerapannya di Indonesia, Buku Litera, Jogjakarta, 2011.

Syahrizal, Hukum Adat dan Hukum Islam di Indonesia: Refleksi terhadap Beberapa Bentuk Integrasi Hukum dalam Bidang Kewarisan di Aceh, Yayasan Nadiya, Lhokseumawe, 2004.

Syahrizal, Mediasi Dalam Hukum Syariah, Hukum Adat dan Hukum Nasional, Kencana, Jakarta, 2011.

\section{Hasil Penelitian/Tugas Akhir}

Kelompok Kerja Akses terhadap Keadilan, “Strategi Nasional Akses Terhadap Keadilan, Kementerian Negara Perencanaan Pembangunan Nasional/BAPPENAS", Hasil Penelitian, Jakarta, 2009.

Laudjeng, Hedar, "Mempertimbangkan Peradilan Adat", Hasil Penelitian, Seri Pengembangan Wacana No. 4 - Penerbit Perkumpulan untuk Pembaharuan Hukum Berbasis Masyarakat dan Ekologis (HuMa), The Ford Foundation \& Interchurch Organization for Development Cooperation (ICCO), 2003.

Mahmudin., et.al, "Nilai Lokal dan Konflik Aceh: Studi Dimensi Budaya Dalam Penguatan Civil Society", Hasil Penelitian, Satker BRR Revitalisasi dan Pengembangan Kebudayaan NAD, Banda Aceh, 2006.

Perdana Wiratraman, Herlambang, "Laporan Akhir Tim Pengkajian Hukum Tentang Peluang Peradilan Adat dalam Menyelesaikan Sengketa Antara Masyarakat Hukum Adat dengan Pihak Luar", Hasil Penelitian, Pusat Penelitian dan Pengembangan Sistem Hukum Nasional - BPHN, Kementerian Hukum dan HAM, Jakarta, 2013.

Salim, Arskal, "Praktek Penyelesaian Formal dan Infomal Masalah Pertanahan, Kewarisan dan Perwalian Pasca Tsunami di Banda Aceh dan Aceh Besar", Hasil Penelitian, IDLO, Banda Aceh, 2006.

\section{Artikel Jurnal}


Abdurrahman, "Penyelesaian Sengketa Melalui Pendekatan Adat", dalam Qanun Jurnal Ilmu Hukum No. 50 Edisi April 2010, FH Unsyiah, Banda Aceh, 2010.

Hasan, Ahmadi, "Penyelesaian Sengketa Melalui Upaya Non Litigasi Menurut Peraturan Perundang-undangan", Jurnal AL-BANJARI, Vo. 5, No. 9, Januari - Juni, 2007.

Husin, Taqwaddin, "Penyelesaian Sengketa/Perselisihan Secara Adat Gampong di Aceh", Kanun Jurnal Ilmu Hukum, No. 67, Tahun XVII (Desember, 2015), halaman $511-532$.

Mahdi, "Eksistensi Peradilan Adat di Aceh", Hunafa: Jurnal Studia Islamika, Vol. 8 Nomor 2, Desember, 2011.

Nurdin, Abidin, "Revitalisasi Kearifan Lokal di Aceh: Peran Budaya dalam Menyelesaikan Konflik Masyarakat", Journal Analisis, Volume XIII, Nomor 1, Juni, 2013.

Salim, Arskal, “Pluralisme Hukum di Indonesia: Keberadaan Hukum Islam dalam Peraturan Perundang-Undangan Indonesia", HARMONI Jurnal Multikultural dan Multireligius, Volume VII, No. 28, Oktober - Desember, 2008.

Sasmita Jiwa Utama, Tody \& Sandra Dini Febry Aristya, “Kajian tentang Relevansi Peradilan Adat terhadap Sistem Peradilan Perdata Indonesia", Mimbar Hukum, Volume 27, Nomor 1, February, 2015.

Sudrajat, Tedy, "Aspirasi Reformasi Hukum dan Penegakan Hukum Positif Melalui Media Hakim Perdamaian Desa", Jurnal Dinamika Hukum, Volume 10 No 3 Desember 2010, halaman 291 - 300.

\section{Makalah/Pidato}

Arizona, Yance, "Kedudukan Peradilan Adat dalam Sistem Hukum Nasional", Makalah disampaikan pada Diskusi tentang Memperkuat Peradilan Adat di Kalimantan Tengah untuk Penguatan Akses terhadap Keadilan, 11 Juni 2013.

Juniarti, "Peran Strategis Peradilan Adat di Aceh dalam Memberikan Keadilan Bagi Perempuan dan Kaum Marjinal", Makalah disampaikan pada Annual International Conference on Islamic Studies XII, Surabaya, 2012.

Mulyadi, Lilik, "Hukum dan Putusan Adat dalam Peradilan Negara", Makalah disampaikan dalam Dialog Nasional Bersama Perkumpulan HuMa dan Mahkamah Agung, Royal Kuningan, 10 Oktober 2013.

Simarmata, Ricardo, "Merumuskan Peradilan Adat dalam Sistem Peradilan Nasional", Makalah disampaikan pada Seminar "Merumuskan Kedudukan Peradilan Adat dalam Sistem Peradilan Nasional", diselenggarakan bersama oleh Perkumpulan HuMA dan Mahkamah Agung Republik Indonesia, Jakarta 10 Oktober 2013.

\section{Internet}


"Hukum dan Putusan Adat dalam Praktek Peradilan Negara", http:/ / fakhukum.untagsmg.ac.id/, diakses tanggal 20 Februari 2017.

"Menteri Sofyan Dorong Restorative Justice", https://www.bappenas.go.id/id/berita-dan-siaran-pers/menteri-sofyandorong-restorative-justice/, diakses pada tanggal 9 Juli 2016.

\section{Peraturan Perundang-Undangan}

Undang-Undang Nomor 44 Tahun 1999 tentang Penyelenggaraan Keistimewaan Propinsi Daerah Istimewa Aceh, Lembaran Negara Republik Indonesia Tahun 1999 Nomor 172, Tambahan Lembaran Negara RI Nomor 3893.

Undang-Undang Nomor 11 Tahun 2006 tentang Pemerintahan Aceh Lembaran Negara Republik Indonesia Tahun 2006 Nomor 62, Tambahan Lembaran Negara RI Nomor 4633.

Qanun Aceh Nomor 9 tahun 2008 tentang Pembinaan Kehidupan Adat dan Adat Istiadat Aceh, Lembaran Daerah Nanggroe Aceh Darussalam Tahun 2008 Nomor 9, Tambahan Lembaran Daerah Nanggroe Aceh Darussalam Nomor 19.

\section{Lain-lain}

Majelis Adat Aceh (MAA), Pedoman Peradilan Adat Aceh - Untuk Peradilan Adat Yang Adil dan Kompatibel, Nanggroe Aceh Darussalam, 2008.

Mahkamah Agung, Cetak Biru Pembaruan Peradilan 2010 - 2035, Jakarta, 2010.

Keputusan Bersama (SKB) antara Gubernur Aceh dengan Kepolisian Daerah Aceh dan Majelis Adat Aceh (MAA) melalui Nomor SKB sebagai berikut: 189/677/2011, 1054/MAA/XII/2011, B/121/I/2012 tentang Penyelenggaraan Peradilan Adat Gampong dan Mukim atau nama lain di Aceh. 